\title{
NO CHILD LEFT BEHIND: THE ADAM WALSH ACT AND PENNSYLVANIA JUVENILE SEX OFFENDERS
}

\author{
Neal F. Wilson*
}

\section{INTRODUCTION}

At a White House ceremony on July 27, 2006, President Bush signed into law the Adam Walsh Child Protection and Safety Act of 2006. ${ }^{1}$ At the ceremony, the President hailed the Walsh Act as being comprehensive and an important part of the "solemn responsibility" of lawmakers to protect children. ${ }^{2}$ Indeed, the Walsh Act is the latest in a series of federal legislation, dating back to the 1980 s, which aims to protect the public, and children in particular, from becoming victims of sexual crimes. The public's fear of the rapist and the child molester led to a great increase in the criminal penalties for sexual crimes throughout the 1980s and 1990s, ${ }^{3}$ as well as the imposition of federal laws focusing on these crimes. ${ }^{4}$ And at a time when television shows such as "To Catch a Predator" receive millions of viewers, ${ }^{6}$ it is clear that the nation's fear of those who would commit sexual crimes against children, and the desire that they be brought to justice, remains at a fever pitch. By passing the Walsh Act, Congress and the President responded to a national outcry that children were not safe from sex offenders.

Though the intent was to protect children, the Walsh Act also serves to hurt a group of the nation's children. Like equivalent laws in other states, Pennsylvania's Juvenile Act lists among its goals "care and rehabilitation."7

* J.D. Candidate, 2009, University of Pittsburgh School of Law.

1. Press Release, Office of the Press Sec'y, President Signs H.R. 4472, the Adam Walsh Child Prot. and Safety Act of 2006 (July 27, 2006), available at http://www.whitehouse.gov/news/releases/2006/ 07/20060727-6.html.

2. $I d$.

3. Franklin E. Zimring, An American Travesty 26 (2004).

4. See, e.g., 42 U.S.C. § 14071 (2006).

5. "To Catch a Predator" is a television series that investigates adults who contact minors over the internet seeking sexual liaisons. See Dateline, http://www.msnbc.msn.com/id/10912603/ (last visited Jan. 7, 2009).

6. Brian Stelter, "To Catch a Predator" Is Falling Prey to Advertisers'Sensibilities, N.Y. Times, Aug. 27, 2007, at C3.

7. 42 Pa. Cons. Stat. $§ 6301(b)(2)(2006)$. 
The Juvenile Act seeks not just to punish children accused of committing crimes, but to rehabilitate them so they may grow up to become productive members of society. Some tenets of the Walsh Act run counter to these goals.

The stereotypical image of a "sexual predator" is rarely a juvenile, ${ }^{8}$ but in times when national concern over protecting children from these "predators" is at its highest, the effects often "spill over" into policies that have a direct impact on juvenile sex offenders. ${ }^{9}$ The Walsh Act requires states to enact its provisions by $2009 .{ }^{10}$ In Pennsylvania, several bills that would change the criminal code to comply with the Walsh Act have already been introduced. ${ }^{11}$ Lawmakers in Pennsylvania should take care, however, to ensure that juvenile sex offenders are not the children left behind.

This Note begins with an overview of Pennsylvania's Juvenile Act and the provisions of the Walsh Act. It then examines problems with the Walsh Act's treatment of juvenile sex offenders, the assumptions underlying the Walsh Act, and the conflicts between the Walsh Act's registration and notification requirements and the Pennsylvania Juvenile Act. I argue that registration and notification requirements of the Walsh Act run contrary to the goals of Pennsylvania's Juvenile Act by seeking to punish rather than rehabilitate juvenile sex offenders. Finally, I propose ways in which Pennsylvania lawmakers can ensure that in complying with the Walsh Act they do not sacrifice the goals and objectives of the Juvenile Act.

\section{Brief Overview of Pennsylvania Juvenile Law}

Pennsylvania's Juvenile Act lists among its purposes the following: "to provide for children committing delinquent acts programs of supervision, care and rehabilitation which provide balanced attention to the protection of the community, the imposition of accountability for offenses committed and the development of competencies to enable children to become responsible and productive members of the community." "2 This statement of purpose illustrates the crucial difference between the goals of juvenile law and those of criminal law. Whereas criminal trials seek to establish blameworthiness, the focus of juvenile law is "care and rehabilitation." 13 This fundamental

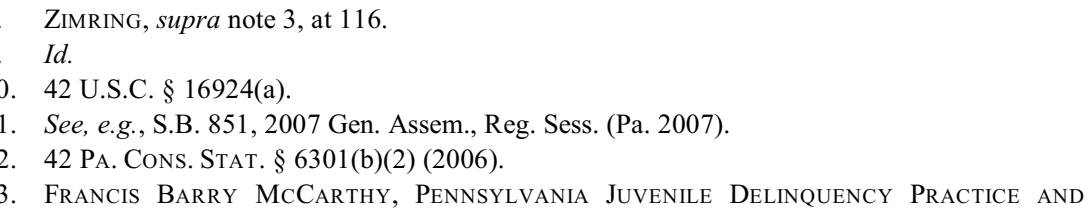


difference, between juvenile and criminal law, requires the different treatment of juvenile and adult sex offenders.

A juvenile accused of committing a crime is usually subject to a delinquency adjudication. Generally, the public is excluded from delinquency adjudications ${ }^{14}$ because privacy and confidentiality are crucial elements of juvenile proceedings, unlike in criminal trials. ${ }^{15}$ The purpose of delinquency adjudications is to determine whether the child committed a delinquent act; a delinquent act is an act designated a crime under Pennsylvania code. ${ }^{16}$ However, several serious offenses, including rape and involuntary deviate sexual intercourse, are not delinquent acts if committed by a child aged fifteen or older who used a deadly weapon in the course of committing the crime. ${ }^{17}$ Although trial by jury is an essential part of the criminal process, jury trials are not constitutionally required in delinquency hearings. ${ }^{18}$ In delinquency hearings, the juvenile is entitled to counsel, the right to confront and crossexamine witnesses, and the privilege against self-incrimination. ${ }^{19}$ But the Juvenile Act states that the proceedings shall take place in an informal manner, meaning that the judge has wide discretion in assuring that the truth comes out, sometimes at the expense of the Rules of Evidence. ${ }^{20}$ For example, in certain situations, hearsay may be admissible in juvenile proceedings. ${ }^{21}$ In fact, some view legal procedures in juvenile proceedings as an impediment to the process..$^{22}$ Additionally, juvenile law allows probation officers and judges to steer children accused of crimes into diversion programs that allow for supervision of the children without an adjudication of delinquency. ${ }^{23}$ These procedural differences between juvenile delinquency and criminal proceedings underscore the problems with imposing similar punishments on juvenile and adult sex offenders.

Another important distinction between juvenile and criminal law exists in the outcome of the proceedings. If successful, a criminal prosecution results

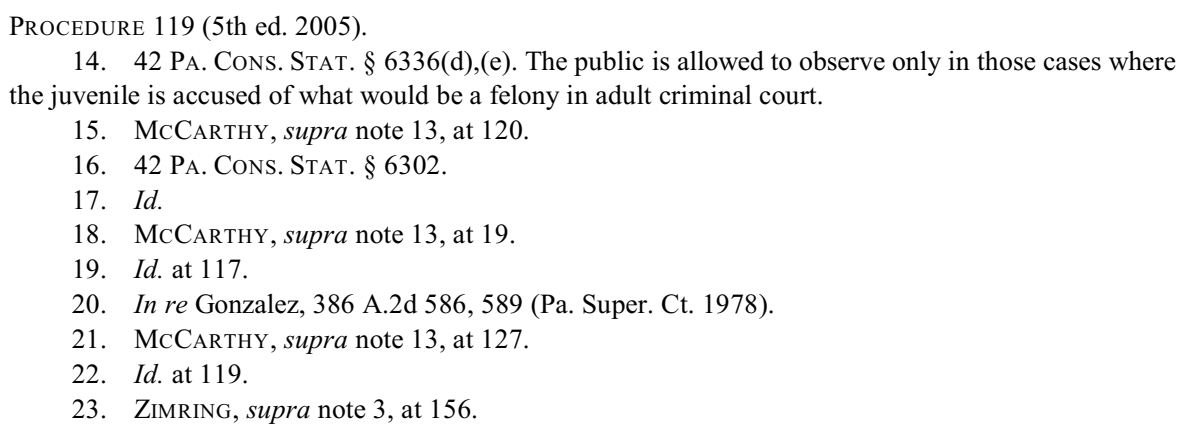


in a conviction. A delinquency adjudication results in a determination that the child is delinquent. Pennsylvania law states that a delinquency adjudication is not equivalent to a criminal conviction and does not carry any "civil disability ordinarily resulting from a conviction." ${ }^{24}$ The statute lists only limited circumstances in which the adjudication may later be used against the child. ${ }^{25}$ An adult convicted of a violent crime, who has two previous violent crime convictions, may face a minimum of twenty-five years in prison, ${ }^{26}$ but delinquency adjudications cannot be used against an accused in such "three strikes" prosecutions. ${ }^{27}$ The disparity in the outcomes and effects of juvenile and criminal proceedings underscore the differences in the goals of juvenile and criminal law.

The specific goals of the Juvenile Act, which include balancing accountability with the need to properly care for the child, create a unique process in delinquency adjudications. With an emphasis on rehabilitation, rather than on punishment or retribution, delinquency adjudications have long been considered distinct from criminal trials and convictions.

\section{The Adam Walsh Child Protection and Safety Act of 2006}

The Walsh Act was passed to "protect the public from sex offenders and offenders against children." ${ }^{28}$ It is wide ranging in its scope and its effects. It increases federal criminal penalties for a multitude of crimes committed against children, ${ }^{29}$ increases penalties for crimes associated with child pornography, ${ }^{30}$ and awards numerous grants for research and crime prevention. ${ }^{31}$ But the Act's most comprehensive reform deals with the registration of sex offenders. Title I requires the individual jurisdictions of the U.S. to create registries of sex offenders. ${ }^{32}$ It also requires each jurisdiction to publish certain information ${ }^{33}$ about the offenders on a website. ${ }^{34}$ The Walsh Act divides sex offenders into three tiers, with the registration requirements

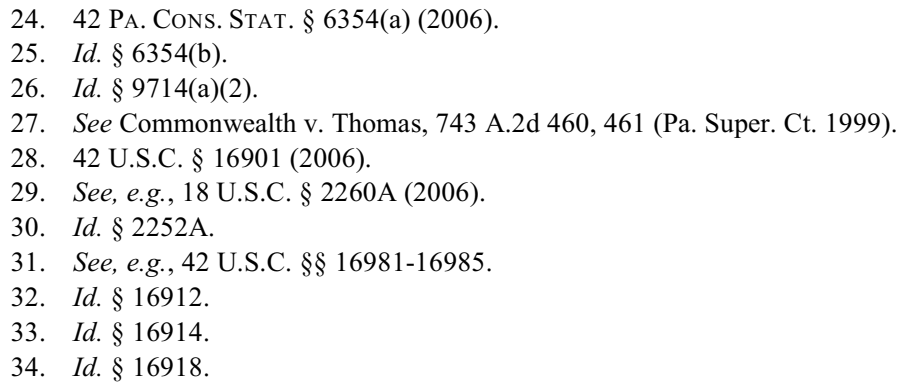


varying for each tier. The length of registration varies from fifteen years for Tier I offenders to life for Tier III offenders. ${ }^{35}$ The offender must appear in person to have his or her photograph taken for the registry, with the frequency of these visits again depending on the classification of the offender. ${ }^{36}$ If offenders meet certain conditions, they may be eligible to have their registration periods shortened..$^{37}$ In addition, the Walsh Act mandates the creation of a national sex offender registry ${ }^{38}$ and a publicly accessible web site for this national database. ${ }^{39}$ When a sex offender registers or changes information that is pertinent to the local and national registry, local law enforcement is to notify various municipal or volunteer organizations that might have an interest in the information. ${ }^{40}$

The Walsh Act also mandates harsh penalties for offenders who fail to register. An offender who fails to register could face fines or a prison sentence of up to ten years. ${ }^{41}$ In addition, if the offender was convicted of a "violent offense" and failed to register, the offender could face an additional five to thirty years in prison. ${ }^{42}$ Similarly, the Walsh Act requires jurisdictions to abide by its provisions in a timely manner. Jurisdictions have three years from the passage of the Walsh Act to implement the provisions it requires. ${ }^{43}$ If a jurisdiction does not "substantially implement" the Walsh Act, it will not receive ten percent of the funds it would normally receive from the Omnibus Crime Control and Safe Streets Act. ${ }^{44}$ The Attorney General is permitted to make accommodations if a jurisdiction cannot implement parts of the Walsh Act due to state constitutional concerns. ${ }^{45}$

The provisions of the Walsh Act that have the greatest effect on juvenile sex offenders can partially be credited to Amie Zyla. A fourteen-year-old boy sexually assaulted Zyla when she was eight years old. ${ }^{46}$ Years later, Zyla saw a news report of the same man arrested on multiple charges of sexual crimes

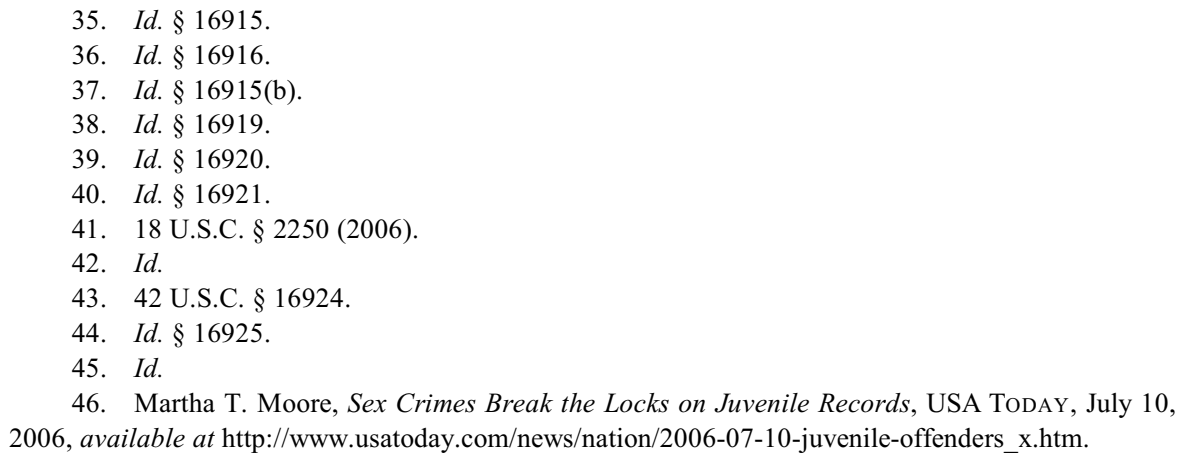


against children. ${ }^{47}$ She then advocated before the Wisconsin legislature and the United States Congress to require juvenile sex offenders to register on the same public registries as adult sex offenders. ${ }^{48}$ Partially thanks to her advocacy, the Walsh Act includes a section titled "Sex Offender Registration and Notification Act." 49 This section includes broad definitions of "sex offenses" and "offenses against children." ${ }^{50}$ The Walsh Act also states that certain juveniles who are adjudicated delinquent will fall under the scope of the Act's requirements. The Walsh Act states that the term "convicted" includes an adjudication of delinquency if the offender is at least fourteen years old and the offense adjudicated is comparable or more severe than the federal crime of aggravated sexual assault, or if the offender made an attempt or was involved in a conspiracy to commit such a crime. ${ }^{51}$ Consequently, a juvenile offender adjudicated delinquent of such an offense would be subject to the Walsh Act's registration requirements.

\section{Problems with the Walsh Act for Pennsylvania's Juvenile Sex Offenders}

Treating juvenile adjudications of delinquency like convictions for purposes of registering sex offenders undermines the Juvenile Act's emphasis on treatment, rather than punishment and privacy. Requiring sex offenders to register is not new in Pennsylvania. Like all states, Pennsylvania enacted several laws to conform to Megan's Law, enacted by Congress after a sevenyear-old New Jersey girl was raped and killed by a neighbor who had been previously incarcerated for sexual crimes. ${ }^{52}$ The federally mandated laws focus on registering convicted sex offenders with the police after their release and providing the public with general information about the offenders and the crimes they committed. The registration periods vary, spanning from ten years for certain offenses to life for more serious convictions. ${ }^{53}$ The statute also provides that police in the offender's jurisdiction notify neighbors, superintendents of nearby schools, and owners of nearby daycare facilities of

47. Kimberly Oasis, Teen Pushes Change in Youth Sex Offender Laws, CNN, June 9, 2005, available at $\mathrm{http}: / / \mathrm{www} . \mathrm{cnn} . \mathrm{com} / 2005 / \mathrm{US} / 06 / 09 /$ amies.law/index.html.

48. $I d$.

49. 42 U.S.C. $\S 16911$ (2006).

50. $I d$.

51. Id.

52. ZimRING, supra note 3, at 5.

53. 42 Pa. Cons. STAT. § 9795.1 (2006). 
the offender's location and provide them with a photograph. ${ }^{54}$ Moreover, affected communities are given access to relevant information about the offender via the Internet..$^{55}$ An important distinction between Megan's Law and the Walsh Act is that the federal version of Megan's Law neither requires nor prohibits the registration of juvenile sex offenders who are adjudicated in juvenile court. ${ }^{56}$ Pennsylvania opted not to require registration for juveniles who are found delinquent in adjudications involving sexual offenses. However, many states do require these juveniles to register, ${ }^{57}$ and Pennsylvania law requires a person registered as a sex offender in another state to register in Pennsylvania if he or she takes up residence there. ${ }^{58}$ The Walsh Act would bring Pennsylvania in conformity with states that already require juvenile sex offenders to register through Megan's Law.

Several bills that seek to enact the Walsh Act have been introduced into the Pennsylvania General Assembly's House and Senate. ${ }^{59}$ However, to date, none of the proposed bills address requiring juvenile sex offenders to register. It is an issue the legislature will have to confront eventually because the current federal guidelines for implementing the Walsh Act provide that the law sets a minimum standard the states must abide by ${ }^{60}$ Specifically, the Walsh Act requires that juveniles register under the Act's provisions if they are at least fourteen years old and if they are adjudicated delinquent of an offense "comparable to or more severe than" the federal crime of aggravated sexual abuse. ${ }^{61}$ The crime of aggravated sexual abuse is defined as "knowingly causing another to engage in a sexual act" either by force, threat, or other coercion, or as engaging in a sexual act with a child under twelve. ${ }^{62}$ Committing such an offense would make the juvenile a "Tier III" offender under the Walsh Act, the category with the strictest punishments and the lifetime registration requirement. ${ }^{63}$ The equivalent Pennsylvania offenses would likely include sexual exploitation of children, certain cases of incest, aggravated indecent assault, sexual assault, involuntary deviate sexual

54. Id. § 9798(b).

55. Id. $\S 9798.1$.

56. ZIMRING, supra note 3, at 147.

57. Id. at 148

58. 42 Pa. Cons. STAT. § 9795.2(b)(5).

59. See, e.g., 42 U.S.C. $§ 14071$ (2006).

60. The National Guidelines for Sex Offender Registration and Notification, 73 Fed. Reg. 38,030, 30,032 (July 2, 2008), available at http://www.ojp.usdoj.gov/smart/pdfs/fr_2008_07_02.pdf.

61. 42 U.S.C. $\S 16911(8)(2006)$

62. 18 U.S.C. $\$ 2241(2006)$.

63. 42 U.S.C. § 16911(3), (5)(a)(3). 
intercourse, and rape.$^{64}$ Although some of these crimes, if committed by a juvenile of a certain age, would make the child eligible to be charged criminally in adult court, many are still routinely adjudicated in juvenile court. $^{65}$ The imposition of the Walsh Act's reporting requirements would represent a dramatic shift in the impact of adjudications on juvenile sex offenders. Juveniles in Pennsylvania who are found delinquent in an adjudication for the above crimes are currently entitled to the privacy protections of the Juvenile Act. But the Walsh Act would require juveniles fourteen years or older who are adjudicated delinquent for these crimes to register for the remainder of their lives.

One of the major flaws in the Walsh Act's treatment of juvenile sex offenders is that it subjects them to the exact same registration requirements as adult sex offenders. As discussed above, juvenile adjudications and criminal trials are very different in both purpose and procedure. ${ }^{66}$ While an adult sex offender will enjoy the right to a trial by jury with constitutional and other protections prior to facing the registration requirements of the Walsh Act, a juvenile sex offender could face those lifelong punishments as the result of a highly informal proceeding that lacks a jury and many other procedural protections observed in criminal trials ${ }^{67}$ Unlike the accused in criminal court, a juvenile sex offender is not entitled to bail or a public trial. ${ }^{68}$ It is also unclear whether juveniles who are stopped or interrogated by school officials are protected by the same constitutional considerations that protect adults interrogated by police. ${ }^{69}$ The Pennsylvania Post-Conviction Relief Act, a statute passed to allow wrongfully convicted persons to seek collateral relief, ${ }^{70}$ cannot be used to challenge an adjudication of delinquency since it applies only to convictions. ${ }^{71}$ The informal nature of delinquency adjudications reflects the underlying policy of the Juvenile Act that focuses the adjudication on reaching the best outcome for the accused child. But the Walsh Act undercuts that policy by using the informality of adjudications to ensure juvenile sex offenders can be punished as severely as adult sex offenders but without affording them the same constitutional protections.

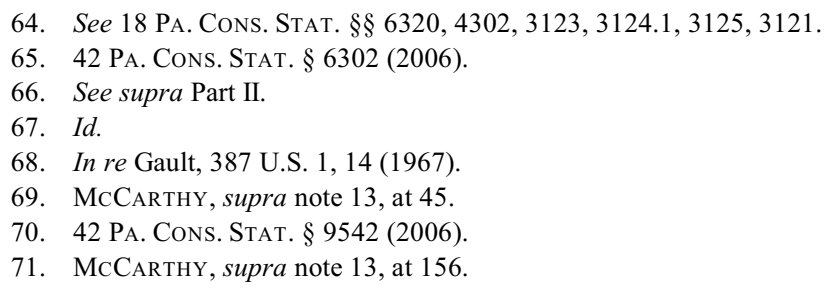


By subjecting juvenile sex offenders to the same registration and notification requirements as adults, the Walsh Act groups all sex offenders into one category (dividing them only based on the severity of the offense) and assumes there are significant differences between juvenile sex offenders and other delinquents. In reality, there are significant differences between juvenile sex offenders and adult sex offenders. The Supreme Court has noted that "[f]rom a moral standpoint it would be misguided to equate the failings of a minor with those of an adult." "' Juvenile offenders sometimes lack the ability to gauge the consequences of their actions and are often acting out of a combination of "hormones and opportunity," whereas adult sex offenders often suffer from mental disorders that increase their propensity to commit sexual crimes. ${ }^{73}$ The Diagnostic and Statistical Manual of Mental Disorders refuses to recognize a diagnosis of pedophilia in younger teens. ${ }^{74}$ A number of other factors suggest a "minimal presence" of psychological disorders in juvenile sex offenders compared to adult sex offenders. ${ }^{75}$ Experts estimate that ten percent or fewer of juvenile sex offenders are afflicted with disorders common among adult sex offenders. ${ }^{76}$

The assumption that all sex offenders have high rates of mental disorders serves to justify the registration and notification requirements of the Walsh Act. While the evidence that adult sex offenders exhibit an unusually high recidivism rate is questionable ${ }^{77}$ the evidence that juvenile sex offenders show high rates of recidivism is even more dubious. ${ }^{78}$ In one study, researchers tracked seventy-two juvenile sex offenders (the total released that year) after their release from state institutions. After three years, only three had been arrested again for sexual offenses. ${ }^{79}$ In another study that tracked juvenile sex offenders in three different cities, the recidivism rate for the juveniles ranged from only $3.2 \%$ to $5.5 \% .^{80}$

72. Roper v. Simmons, 543 U.S. 551, 570 (2005).

73. Suzanne Meiners-Levy, Challenging the Prosecution of Young "Sex Offenders": How Developmental Psychology and the Lessons of Roper Should Inform Daily Practice, 79 TEMP. L. Rev. 499, 507 (2006).

74. Id.

75. ZIMRING, supra note 3, at 65 .

76. Id. at 66 .

77. Sarah W. Craun \& Poco D. Kernsmith, Juvenile Offenders and Sex Offender Registries: Examining the Data Behind the Debate, 70 Fed. Probation 45 (2006); see also Adam Shajnfeld \& Richard B. Krueger, Reforming (Purportedly) Non-Punitive Responses to Sexual Offending, 25 Dev. Mental Health L. 81 (2006); Doe v. Miller, 298 F. Supp. 2d 844, 863 (S.D. Iowa 2004).

78. ZIMRING, supra note 3, at 62 .

79. Id. at 57.

80. Id. at 59 . 
Most studies show not only that juvenile sex offenders show lower rates of recidivism than do adult sex offenders, but also that there is little evidence to show their rates of recidivism are higher than juveniles who commit other types of crimes ${ }^{81}$ At a state senate hearing in Ohio on the enactment of the Walsh Act, a representative of the Office of the Ohio Public Defender testified that the rate of recidivism for juvenile sex offenders ranged from "about four to ten percent," while the recidivism rate of juveniles accused of other crimes was thirty percent. ${ }^{82}$ Another study found the overall juvenile delinquent recidivism rate to be forty-five percent, ${ }^{83}$ far higher than the rate of juvenile sex offender recidivism. There is little empirical basis for treating juvenile sex offenders differently from juveniles who commit crimes such as burglary or drug crimes. ${ }^{84}$

Two faulty assumptions underlie the Walsh Act's registration and notification requirements. First, the Act assumes that adult and juvenile sex offenders can be grouped together. Second, the Act assumes that juvenile sex offenders may be treated differently from juveniles who commit other kinds of crimes. On the contrary, the data seems to show that juvenile sex offenders are very different from adult sex offenders and should be subject to the care and rehabilitation-focused dispositions used for other juvenile delinquents.

The registration and notification provisions of the Walsh Act ignore the reality that the goals of juvenile and criminal law are different. Although the Juvenile Act also includes protecting the community and imposing accountability as its goals, its focus is still mainly on care and rehabilitation. ${ }^{85}$ Criminal law is almost exclusively concerned with assigning blame and punishment. Delinquency adjudications are presided over by a judge that is given wide discretion in shaping the course of the proceeding. ${ }^{86}$ The discretion given to the judge in delinquency adjudications and the lack of procedural protections are intended to ensure that the court can care for and find the appropriate disposition for the accused child while protecting the child's privacy. ${ }^{87}$ It is hard to imagine how juvenile law can be reconciled with the registration and notification provisions of the Walsh Act. Imposing a law that

81. Id. at 62,82 .

82. Hearing on S.B. 10 Before the S. Comm. on Crim. Justice, 127th G.A. (Ohio 2006) (testimony of Jill Beeler of the Office of the Ohio Public Defender).

83. Charles A. Schwalbe, Risk Assessment for Juvenile Justice: A Meta-Analysis, 31 Law \& Hum. BeHAv. 449, 454 (2007).

84. ZimRING, supra note 3, at 83.

85. See 42 Pa. Cons. Stat. $§ 6301$ et seq.

86. See In re Gonzalez, 386 A.2d 586, 589 (Pa. Super. Ct. 1978).

87. See McCARthy, supra note 13 , at 15 . 
requires a juvenile sex offender to register with the police for life (and even appear in person to verify the registry information every three months ${ }^{88}$ at the risk of criminal penalty for failing to do $\mathrm{so}^{89}$ ) is clearly a path that has abandoned care, rehabilitation, and privacy and has fully embraced punishment.

\section{Resolving the Conflict Between Juvenile Law and the WALSh ACT}

Before issuing guidelines on the enforcement of the registration and notification provisions of the Walsh Act, the Attorney General invited comments. A great many of the invited comments to the proposed guidelines addressed the issue of juvenile sex offenders. ${ }^{90}$ The comments proposed some compromises as solutions that would balance the goals of the Walsh Act with the need to protect children. Many proposed allowing states to exempt juveniles from the registration or notification requirements of the Walsh Act, while others proposed allowing judges presiding over delinquency adjudications wide discretion in determining whether the circumstances of particular juveniles warrant application of the registration and notification requirements. ${ }^{91}$ In the final guidelines, however, the Attorney General decided that neither of those solutions could qualify as substantial implementation of the Walsh Act. ${ }^{92}$

The final guidelines also attempt to clarify exactly which offenses could subject a juvenile to the registration and notification requirements. When composing the guidelines, the Office of the Attorney General considered whether the Walsh Act could require the registration of a fourteen-year-old that engages in consensual sexual play with an eleven-year-old..$^{33}$ The guidelines stress that the Walsh Act was intended only to bring a certain class of juvenile sex offenders within its auspices. ${ }^{94}$ Consequently, the Office of the Attorney General will consider a state to have substantially complied if it includes offenses that cover engaging in a sexual act with another by force or

88. 42 U.S.C. $\$ 16916(2006)$.

89. Id. § 16922

90. Office of Judicial Programs, SMart Office, Comments on Proposed SORnA GUIDELINES (2007), available at http://www.ojp.usdoj.gov/smart/pdfs/guideline_comments.pdf.

91. Id.

92. The National Guidelines for Sex Offender Registration and Notification, 73 Fed. Reg. 38,030

(July 2, 2008), available at http://www.ojp.usdoj.gov/smart/pdfs/fr_2008_07_02.pdf.

93. Id. at 38,050 .

94. Id. at 38,030 . 
threat of force or engaging in a sexual act by rendering the victim unconscious. ${ }^{95}$ Although this standard somewhat limits the type of offenses that could bring a juvenile under the registration and notification requirements, there are still many Pennsylvania offenses that take force into account. ${ }^{96}$ The guidelines also emphasize that the Walsh Act creates a minimum standard, not a ceiling. ${ }^{97}$

The Pennsylvania legislature, in enacting the provisions of the Walsh Act, could potentially cast a wider net and include many more qualifying offenses than even the guidelines contemplate. In order to do all they can to prevent children as young as fourteen from being subject to the lifelong registration and notification requirements, Pennsylvania lawmakers should require that as few offenses as possible qualify a delinquent minor to fall under the Walsh Act.

Pennsylvania has until July 26, 2009 to enact the provisions of the Walsh Act. ${ }^{98}$ If it does not "substantially comply" by that date, it risks losing substantial federal funding. ${ }^{99}$ Pennsylvania cannot enact the registration and notification requirements of the Walsh Act without significantly undermining its Juvenile Act. However, there may be ways Pennsylvania could pass the Walsh Act, protect the interests of its juvenile sex offenders, and avoid the loss of federal funds.

The easiest way to avoid a conflict between the Walsh Act and the Juvenile Act would be a state constitutional amendment. The Walsh Act contains an exception that states that the Attorney General shall not withhold funds if a state cannot enact all or some of the Walsh Act's registration and notification provisions because of conflicts with the state constitution. ${ }^{100}$ If the Pennsylvania legislature passes a state constitutional amendment that definitively separates juvenile adjudications and criminal convictions, it would be unable to enact a statute that defines certain adjudications as convictions. While this would likely resolve the conflict, passing such a constitutional amendment would be a lengthy and difficult process. ${ }^{101}$ Amending the state constitution requires votes in both houses of the General

95. Id.

96. See supra Part IV.

97. National Guidelines for Sex Offender Registration and Notification, 73 Fed. Reg. at 38,032.

98. 42 U.S.C $\S 16924(\mathrm{a})(1)(2006)$.

99. Id. § 16925.

100. Id.

101. PA. Cons. art. XI. 
Assembly and a majority vote statewide. ${ }^{102}$ It is unlikely this could be accomplished by July 2009, if at all.

There are still some options for Pennsylvania to protect the interests of its juvenile sex offenders. Pennsylvania could mandate that all juveniles accused of crimes that would qualify as "convictions" under the Walsh Act must be tried in criminal court instead of juvenile court. This suggestion was brought up in the Ohio Senate hearings on Ohio's version of the Walsh Act. ${ }^{103}$ Although this requirement could bring young teenagers into adult criminal court, it will ensure them the constitutional protections lacking in delinquency adjudications. Being in criminal court may also provide juvenile offenders with a few tactical advantages lacking in delinquency adjudications, such as the ability to plea bargain with prosecutors. ${ }^{104}$ This solution abandons many of the policies of the Juvenile Act, but it would at least prevent a juvenile from receiving a lifetime punishment without having the right to a trial by jury and the other protections provided in criminal court.

Pennsylvania could enact a blanket rule requiring that all adjudications that could result in a juvenile sex offender being subject to the Walsh Act's registration and notification provisions contain all of the procedural protections of a criminal trial, including a jury. This is the solution that, barring total exemption of juveniles from the Walsh Act, the Office of the Ohio Public Defender favored in its testimony to the state senate during hearings on Ohio's enactment of the Walsh Act. ${ }^{105}$ The addition of formal procedural requirements in the delinquency adjudication process would undermine some of the goals of the Juvenile Act because the judge would no longer have a large amount of discretion to use in working with the prosecution and defense to determine the best outcome for the child. However, procedural safeguards would prevent the prosecution from using the existing informalities in delinquency adjudications to burden juvenile sex offenders with lifelong, criminal-type punishments.

In the Gault case, the United States Supreme Court quoted Justice Frankfurter, who wrote that " $[\mathrm{t}]$ he history of American freedom is, in no small measure, the history of procedure."”106 The Court added, "[T] he procedural

102. Id.

103. Hearing on S.B. 10 Before the S. Comm. on Crim. Justice, supra note 82. (1991).

104. Dean J. Champion \& G. Larry Mays, Transferring Juveniles to Criminal Courts 93

105. Id.

106. In re Gault, 387 U.S. 1, 21 (1967) (quoting Malinski v. People of State of N.Y., 324 U.S. 401, $414(1945))$. 
rules which have been fashioned from the generality of due process are our best instruments for the distillation and evaluation of essential facts." ${ }^{107}$ The addition of criminal trial procedure could help protect juvenile sex offenders in the face of the consequences of the Walsh Act. In the absence of a state constitutional amendment, at least some of the goals of the Juvenile Act will have to be sacrificed.

\section{CONCLUSION}

Congress passed the Adam Walsh Child Protection and Safety Act of 2006 with the noblest of intentions-protecting children nationwide. But along the way, the drafters of the legislation forgot about juvenile sex offenders, a group of children that also deserves protection. The application of the registration and notification provisions to certain juvenile sex offenders who are adjudicated delinquent of specific offenses intends to serve the dual functions of allowing law enforcement to supervise potentially dangerous individuals and to notify the community of their presence. However, in light of data concerning recidivism, the grouping of juvenile sex offenders with adult offenders is troubling, as is the separation of juvenile sex offenders from other juveniles who are adjudicated delinquent. Also troubling is the Walsh Act's imposition of a lifetime punishment upon children whom are adjudicated delinquent at a hearing without a jury or many of the procedural safeguards of a trial. Juvenile sex offenders who must abide by the registration and notification provisions will be subject to lifetime registration and will face harsh punishment for failure to register, appear in person, or update their information. This requirement will leave them open to a lifetime of stigmatization and ridicule. It will likely also provide a great burden on police and other state officials who must monitor individuals who committed a crime when they were as young as fourteen, and who are unlikely to commit another sexual offense.

Most troubling of all is how the registration and notification provisions ignore the fundamental differences between juvenile and criminal law. Juvenile law values the importance of privacy, whereas the Walsh Act would broadcast private information (including names, addresses, photographs, criminal records, and possibly even employment and/or school information) about children to the world. Juvenile law seeks to impose accountability, but its focus is on care and rehabilitation so that children can grow up to become 
productive members of the community. The Walsh Act equates certain juvenile delinquency adjudications with criminal convictions and imposes criminal penalties that carry lifelong ramifications. The Walsh Act undermines the most basic tenets of juvenile law.

Pennsylvania lawmakers have until July 2009 to substantially comply with the Walsh Act or the state will face a loss of federal funds. Challenges to sex-offender statutes in the courts have been largely unsuccessful. ${ }^{108}$ It is in the hands of Pennsylvania lawmakers to address the problems the Walsh Act poses for the Juvenile Act. When drafting Pennsylvania's version of the Walsh Act, lawmakers should take care not to make the same mistake the drafters of the federal version made by sacrificing the needs of one group of children for the protection of another. They should not be "misguided," as the Supreme Court warned in Roper, by equating the harmful acts of a child with the harmful acts of an adult. ${ }^{109}$ The lawmakers should seek to find a middle ground and balance the need to protect children from sex offenders with the need to protect children who commit sexual offenses.

108. Bret R. Hobson, Note, Banishing Acts: How Far May States Go To Keep Convicted Sex Offenders Away From Children?, 40 GA. L. REv. 961, 966-67 (2006).

109. See Roper v. Simmons, 543 U.S. 551, 570 (2005). 